\title{
Influenza Virus Assembly and Lipid Raft Microdomains: a Role for the Cytoplasmic Tails of the Spike Glycoproteins
}

\author{
JIE ZHANG, ${ }^{1}$ ANDREW PEKOSZ, ${ }^{2}$ AND ROBERT A. LAMB ${ }^{1,2 *}$ \\ Department of Biochemistry, Molecular Biology and Cell Biology ${ }^{1}$ and Howard Hughes Medical Institute, ${ }^{2}$ \\ Northwestern University, Evanston, Illinois 60208-3500
}

Received 5 January 2000/Accepted 16 February 2000

\begin{abstract}
Influenza viruses encoding hemagglutinin (HA) and neuraminidase (NA) glycoproteins with deletions in one or both cytoplasmic tails (HAt - or NAt-) have a reduced association with detergent-insoluble glycolipids (DIGs). Mutations which eliminated various combinations of the three palmitoylation sites in HA exhibited reduced amounts of DIG-associated $\mathrm{HA}$ in virus-infected cells. The influenza virus matrix $\left(\mathrm{M}_{1}\right)$ protein was also found to be associated with DIGs, but this association was decreased in cells infected with HAt- or NAtvirus. Regardless of the amount of DIG-associated protein, the HA and NA glycoproteins were targeted primarily to the apical surface of virus-infected, polarized cells. The uncoupling of DIG association and apical transport was augmented by the observation that the influenza $A$ virus $M_{2}$ protein as well as the influenza $C$ virus HA-esterase-fusion glycoprotein were not associated with DIGs but were apically targeted. The reduced DIG association of HAt - and NAt - is an intrinsic property of the glycoproteins, as similar reductions in DIG association were observed when the proteins were expressed from cDNA. Examination of purified virions indicated reduced amounts of DIG-associated lipids in the envelope of HAt - and NAt - viruses. The data indicate that deletion of both the HA and NA cytoplasmic tails results in reduced DIG association and changes in both virus polypeptide and lipid composition.
\end{abstract}

It was long thought that the lipids of the plasma membrane functioned mainly as a solvent for membrane proteins (the fluid mosaic model) (56). However, more recently this view has been refined to include lateral organization resulting from preferential packaging of sphingolipids and cholesterol into moving platforms, or rafts, in which specific membrane proteins become incorporated $(4,55)$. The sphingolipid-cholesterol microdomains can be isolated biochemically due to their insolubility in nonionic detergent at low temperature $(1 \%$ Triton X-100 [TX-100] at $4^{\circ} \mathrm{C}$ ) (4). Detergent-insoluble glycolipid complexes (DIGs) float on sucrose gradients, and thus proteins in DIGs can be separated from other detergent-insoluble material, e.g., cytoskeletal elements $(4,10)$.

The lipids in rafts are in a state similar to the liquid-ordered phase $(3,54)$. This phase separation, which requires cholesterol to form, is favored by lipids like sphingolipids whose long saturated acyl chains confer a high degree of order and a high melting temperature (3), thus explaining detergent insolubility of rafts. Although detergent insolubility has permitted ready identification of proteins in rafts $(4,38,57)$, it is only recently that biophysical evidence has been provided for the existence of rafts in living cells $(12,60)$. Rafts can incorporate specific proteins including many, but not all, glycophosphatidylinositol (GPI)-anchored proteins and N-terminally myristoylated and palmitoylated cytoplasmic proteins $(38,55)$. Rafts also incorporate some integral membrane proteins; among the best studied are the influenza virus hemagglutinin (HA) and neuraminidase (NA) (55). Rafts are thought to function as platforms for events as diverse as intracellular sorting, virus budding, T-cell activation, and signal transduction (4, 41, 42, 52, 55, 58, 64).

For influenza virus HA and NA, among other proteins, it has been suggested that association with rafts constitutes part of

\footnotetext{
* Corresponding author. Mailing address: Department of Biochemistry, Molecular Biology and Cell Biology, Northwestern University, 2153 North Campus Dr., Evanston, IL 60208-3500. Phone: (847) 4915433. Fax: (847) 491-2467. E-mail: ralamb@northwestern.edu.
}

the signaling machinery necessary for apical targeting in polarized cells $(10,28,55)$. However, this is not a fully understood pathway, as some mutations in the HA transmembrane (TM) domain, although not affecting apical sorting, greatly reduced association of HA with DIGs, whereas other TM domain mutations reversed the polarity of HA transport as well as reducing association of HA with DIGs (34). Although it was first thought that the covalent addition of palmitate residues to cysteines in the HA TM domain and cytoplasmic tail were not important for DIG association (53), a more detailed investigation suggested that HA requires three palmitoylated cysteine residues for DIG association (38). Examination of solubility properties of HA, in purified influenza virions and partial analysis of virion-lipid composition, suggests that influenza virus selects cholesterol-sphingomyelin-rich raft domains for the site of assembly of budding virions at the plasma membrane (52).

The HA C-terminal cytoplasmic tail contains 10 or 11 amino acid residues that are highly conserved among the $15 \mathrm{HA}$ subtypes (43). The NA N-terminal cytoplasmic tail contains six residues that are identical for the nine NA subtypes (7). Influenza viruses that lack the cytoplasmic tail of HA (HAt-) (21, $23)$, the cytoplasmic tail of NA (NAt-) $(13,40)$, or both tails (HAt-/NAt - virus) (22) have been generated using reverse genetics procedures. The HAt - virus incorporated HAt - and other virion polypeptides in an amount similar to wild-type (wt) (HA/NA) virus, and the HAt - virions had a spherical morphology similar to that of wt virus grown in eggs. However, the HAt-/NA virions exhibited a somewhat lower budding efficiency and were slightly less infectious than wt virus (21, 22). The HA/NAt - virus had 1- to 2-log-lower infectivity in tissue culture $(13,22,40)$ and exhibited a tendency to form more filamentous than spherical particles $(22,40)$. However, the double mutant HAt-/NAt - virions possess greatly altered morphology. The HAt - /NAt - virus also showed reduced incorporation of NA and matrix $\left(\mathrm{M}_{1}\right)$ protein for an equivalent amount of HA, was 1 to 3 logs lower in infectivity than HA/NA virus, and contained a broader range of number of packaged 
RNA segments than wt virus $(22,68)$. From these observations, we proposed that for normal budding of virions the interactions of the HA and NA cytoplasmic tails with an internal virion component (most likely the $\mathrm{M}_{1}$ protein) are so critical that the cytoplasmic tail signals are dually redundant (22). Given that the site of assembly of budding virions is a cholesterol-sphingomyelin-rich raft domain, we have investigated the association of HAt - and NAt - with rafts when expressed from influenza viruses or from cDNAs, using both polarized and nonpolarized cell types.

\section{MATERIALS AND METHODS}

Cells and viruses. Madin-Darby canine kidney (MDCK) cells and HeLa-T4 cells were maintained in Dulbecco's modified Eagle's medium (DMEM) supplemented with $10 \%$ fetal bovine serum. Baby hamster kidney (BHK) cells were maintained in DMEM supplemented with $10 \%$ tryptose phosphate and $10 \%$ fetal bovine serum. The influenza viruses with HA and NA cytoplasmic tail alterations used in this study (HA/NA, HAt-/NA, HA/NAt-, and HAt-/ $\mathrm{NAt}-$ ) have been described previously (22) ( $\mathrm{t}$ - indicates deletion of a cytoplasmic tail from the indicated protein). RNA segment 4 was derived from A/Udorn/72 (H3 subtype), and the rest of the RNA segments were from A/WSN/33 (N1 subtype). HAt-, which lacks the HA cytoplasmic tail (by insertion in the cDNA of three consecutive stop codons), also contains a substitution of HA cysteine residue 555 for methionine, and this double mutation had at one time been designed Mtr (23). NAt - contains a deletion of the five N-terminal residues of NA occurring after the initiation methionine codon $(13,22)$. The influenza viruses with mutations in the HA palmitoylation sites have also been described previously (23): CAC, CCA, CAY, and MAY represent viruses that contain the indicated amino acid residues at the three HA palmitoylation sites (cysteine residues 555, 562, and 565). HA C/t- virus has an HA that lacks a cytoplasmic tail but retains the palmitoylated transmembrane domain cysteine $_{555}$. Influenza C/Ann Arbor/1/50 virus infections were performed as described previously (47).

Virus purification. Viruses were grown in 11-day-old embryonated eggs or MDCK cells. Allantoic fluids or tissue culture media were clarified by centrifugation at $2,000 \times g$ for $20 \mathrm{~min}$. The virus particles were subsequently pelleted by centrifugation in a Beckman SW41 ultracentrifuge rotor $\left(210,000 \times g, 1 \mathrm{~h}, 4^{\circ} \mathrm{C}\right)$ followed by velocity centrifugation on a 20 to $50 \%$ sucrose gradient at $80,000 \times$ $g$ for $1 \mathrm{~h}$ at $4^{\circ} \mathrm{C}$. Virus bands were extracted and pelleted in an SW41 rotor $\left(210,000 \times g, 1 \mathrm{~h}, 4^{\circ} \mathrm{C}\right)$. Virus pellets were resuspended in NTE buffer $(10 \mathrm{mM}$ Tris [pH 7.4], $100 \mathrm{mM} \mathrm{NaCl}, 1 \mathrm{mM}$ EDTA). Protein concentration was determined using a bicinchoninic acid assay (Pierce Chemical Co., Rockford, Ill.).

Surface biotinylation, TX-100 extraction, and flotation centrifugation. MDCK cells or BHK cells were infected with the indicated viruses for $1 \mathrm{~h}$ at $37^{\circ} \mathrm{C}$ followed by incubation in DMEM. Transfections were performed on subconfluent BHK cells using Lipofectamine (Life Technologies, Gaithersburg, Md.) according to the manufacturer's instructions. The infected or transfected cells were metabolically labeled with [ $\left.{ }^{35} \mathrm{~S}\right]-$ Promix $(100 \mu \mathrm{Ci} / \mathrm{ml}$; Amersham Pharmacia Biotech, Piscataway, N.J.) in DMEM deficient in methionine and cysteine for $30 \mathrm{~min}$ and incubated in chase medium (DMEM plus $2 \mathrm{mM}$ methionine and $2 \mathrm{mM}$ cysteine) for $90 \mathrm{~min}$ at $37^{\circ} \mathrm{C}$. To evaluate the TX-100 solubility properties of proteins expressed at the cell surface, cells were biotinylated in $0.5 \mathrm{ml}$ of phosphate-buffered saline (PBS; pH 8.0) containing NHS-SS-biotin $(1.5 \mathrm{mg} / \mathrm{ml}$; Pierce, Rockford, Ill.) 3 times for 10 min each time as described previously (20). The reaction was quenched by incubating cells in $100 \mathrm{mM}$ glycine in PBS (32). Cells were extracted with $1 \%$ TX-100 in NTE (pH 7.4) on ice for 30 min followed by centrifugation at $120,000 \times g$ for $15 \mathrm{~min}$ to separate the soluble and insoluble fractions. Both the supernatants and the pellets were adjusted to be the same volume and to contain $1 \times$ radioimmunoprecipitation assay (RIPA) buffer (30), and proteins were immunoprecipitated. Antisera used were as follows: for HA and $\mathrm{M}_{1}$, goat serum raised to purified influenza $\mathrm{A} / \mathrm{Udorn} / 301 / 72$ virus; for NA, rabbit anti-N1 serum (Influenza Virus Repository, National Institutes of Health); for $\mathrm{M}_{2}, 14 \mathrm{C} 2$ mouse monoclonal antibody (66); for vesicular stomatitis virus (VSV) G protein, goat anti-VSV serum (kindly provided by John K. Rose, Yale University Medical School). Cell surface expression of HEF (HA-esterase-fusion) glycoprotein was analyzed by susceptibility to cleavage by exogenous trypsin, followed by TX-100 extraction and immunoprecipitation with a cocktail of anti-HEF monoclonal antibodies $(46,59)$. Immunoprecipitated proteins were eluted from protein A-Sepharose beads by boiling with $1 \%$ sodium dodecyl sulfate (SDS), and biotinylated proteins were recovered with streptavidin-Sepharose beads. Polypeptides were analyzed by SDS-polyacrylamide gel electrophoresis (PAGE) (45).

For flotation gradient analysis, the cells were scraped off the dishes after $1 \%$ TX-100 extraction, passed through a 27-gauge needle 15 times, and subjected to Dounce homogenization for 15 strokes. One milliliter of sample was mixed with $3 \mathrm{ml}$ of $65 \%$ (wt/vol) sucrose-NTE, layered on the bottom of an SW41 centrifuge tube, and overlaid with $5.5 \mathrm{ml}$ of $30 \%$ (wt/vol) sucrose-NTE and $2.5 \mathrm{ml}$ of $5 \%$ sucrose-NTE. The gradients were subjected to centrifugation in a Beckman
SW41 rotor at $260,000 \times g$ at $4^{\circ} \mathrm{C}$ for $18 \mathrm{~h}$. Samples of $1 \mathrm{ml}$ were fractionated from the top and analyzed as described above.

Purified ${ }^{35} \mathrm{~S}$-labeled virions were grown in MDCK cells and extracted with $0.1 \%$ TX-100 in NTE for $30 \mathrm{~min}$ on ice. Soluble and insoluble fractions were separated by centrifugation at $120,000 \times g$ for $20 \mathrm{~min}$ at $4^{\circ} \mathrm{C}$, and polypeptides were analyzed by SDS-PAGE.

TX-100 extraction of cholesterol-depleted, virus-infected cells. BHK-21 cells in 12-well plates at $24 \mathrm{~h}$ after plating were incubated in medium in the presence or absence of $4 \mu \mathrm{M}$ lovastatin and $0.25 \mathrm{mM}$ mevalonate (lovastatin-mevalonate) for $48 \mathrm{~h}$ as described previously (25). Cells were then infected with either HA/NA influenza virus or VSV, in the presence or absence of lovastatin-mevalonate, for $1 \mathrm{~h}$ at $37^{\circ} \mathrm{C}$. The medium was replaced with fresh medium with or without lovastatin-mevalonate, and the cells were incubated for $4 \mathrm{~h}$ at $37^{\circ} \mathrm{C}$. Where indicated, infected cells were treated with $1 \mathrm{ml}$ of $10 \mathrm{mM}$ methyl- $\beta$-cyclodextrin in DMEM for $30 \mathrm{~min}$ at $37^{\circ} \mathrm{C}$. The cells were washed twice with DMEM and subsequently metabolically labeled with $\left[{ }^{35} \mathrm{~S}\right]$-Promix $(100 \mu \mathrm{Ci} / \mathrm{ml})$ for $30 \mathrm{~min}$ and incubated in chase medium for $90 \mathrm{~min}$ at $37^{\circ} \mathrm{C}$. The cells were extracted with $1 \% \mathrm{TX}-100$ in NTE $(\mathrm{pH} 7.4)$ on ice for 30 min followed by centrifugation at $120,000 \times g$ to separate the soluble and insoluble fractions. Both the supernatants and the pellets were adjusted to be the same volume and to contain $1 \times$ RIPA buffer, proteins were immunoprecipitated, and polypeptides were analyzed by SDS-PAGE.

Protein targeting assay. MDCK cells were grown on 24-mm-diameter $0.4-\mu \mathrm{m}$ pore-size Transwell polycarbonate filters (Costar Corp., Cambridge, Mass.) as described previously (47a). Influenza virus infections were performed from the apical surface of the cells. Cell surface biotinylation was performed at $5 \mathrm{~h}$ postinfection (p.i.) for influenza A virus or VSV and at $18 \mathrm{~h}$ p.i. for influenza C virus on either the apical or the basolateral side of the cells using NHS-LC-biotin $(1.5 \mathrm{mg} / \mathrm{ml})$ as described above. The cells were then lysed with RIPA buffer. The lysates were subjected to immunoprecipitation with antibodies against HA, NA, $\mathrm{M}_{2}$, or HEF followed by SDS-PAGE analysis. The separated proteins were blotted to polyvinylidene difluoride (PVDF) membranes (45); the surface-biotinylated proteins were detected using alkaline phosphatase-conjugated streptavidin and visualized with Vistra ECF (enhanced chemifluorescence) substrate (Amersham Pharmacia Biotech). Fluorescence was detected by using a STORM fluorescence scanner (Molecular Dynamics, Sunnyvale, Calif.) and quantified using the ImageQuant software (Molecular Dynamics).

Quantitation of relative amounts of $\mathrm{M}_{2}$ versus $\mathrm{HA}$ or NA in purified virions. Sucrose gradient-purified $\mathrm{HA} / \mathrm{NA}, \mathrm{HAt}-/ \mathrm{NA}, \mathrm{HA} / \mathrm{NAt}-$, and $\mathrm{HAt}-/ \mathrm{NAt}-$ were digested with peptidyl $N$-glycanase $\mathrm{F}$ to remove $\mathrm{N}$-linked carbohydrate chains (45); polypeptides were separated by SDS-PAGE and blotted to PVDF membranes. Proteins were detected by using specific antibodies and alkaline phosphatase-conjugated species-specific secondary antibodies and the Vistra ECF substrate. Fluorescence was scanned and quantified as described above.

Lipid composition analysis. Lipids were isolated from $3.2 \mathrm{mg}$ (protein) of sucrose gradient-purified virions and purified as described previously (36). Briefly, the purified virions were extracted with chloroform-methanol $(1: 1, \mathrm{vol} /$ vol) followed by chloroform-methanol-water (30:60:8, vol/vol/vol) and filtered through a glass wool column. The samples were then applied to DEAE-Sephadex (A-25) columns (33). The columns were further eluted with chloroform-methanol-water (30:60:8, vol/vol), and the nonacidic lipids were collected in this fraction. The acidic lipids were then eluted with chloroform-methanol-0.8 M sodium acetate $(30: 60: 8, \mathrm{vol} / \mathrm{vol})$. Both fractions were dried with a stream of $\mathrm{N}_{2}$ and then under vacuum. To remove the sodium acetate, the acidic lipid fractions were further treated with chloroform-methanol-water $(8: 4: 3, \mathrm{vol} / \mathrm{vol})$. The fractions were centrifuged at $800 \times g$ for $5 \mathrm{~min}$. The upper phase was discarded, and an equal volume of chloroform-methanol-water at 3:48:47 (vol/vol) was added. The procedure was repeated, and the upper phase was removed. The lower-phase fractions were dried using $\mathrm{N}_{2}$ and vacuum. Standard lipid mixtures for both the neutral and acidic lipids were made with equal weight of each individual lipid. Standard mixtures containing $1,3,5$, or $10 \mu \mathrm{g}$ of each individual standards were applied onto the high-performance thin-layer chromatography (HPTLC) plates along side the samples. The neutral lipid fractions were chromatographed using chloroform-methanol-acetic acid-formic acid-water (35:15:6:2:1, vol/vol) followed by a second chromatography step using hexane-isopropylether-acetic acid $(65: 35: 2, \mathrm{vol} / \mathrm{vol})$. Excess solvent was evaporated in a fume hood and then in a vacuum desiccator. The HPTLC plates were dipped into a $3 \%(\mathrm{wt} / \mathrm{vol})$ cupric acetate $-8 \%(\mathrm{vol} / \mathrm{vol})$ phosphoric acid solution and heated at $180^{\circ} \mathrm{C}$ for $15 \mathrm{~min}$. Lipid components were quantified from HPTLC plates by densitometric scanning and comparison with standard curves (36), using NIH image software.

Chemicals. Lipid standards (sulfatides, cholesterol, triolein, oleyl alcohol, galactocerebrosides, and phospholipids) were from Sigma Chemical Co., St. Louis, Mo., and GM3 was from Calbiochem, San Diego, Calif. HPTLC plates were from E-Merk, Gibbstown, N.J., and A-25 DEAE-Sephadex was from Amersham Pharmacia Biotech.

\section{RESULTS}

Deletion of the HA and NA cytoplasmic tail diminishes raft association of the spike glycoproteins but has no effect on exclusion of the $\mathrm{M}_{2}$ ion channel protein from rafts. To exam- 


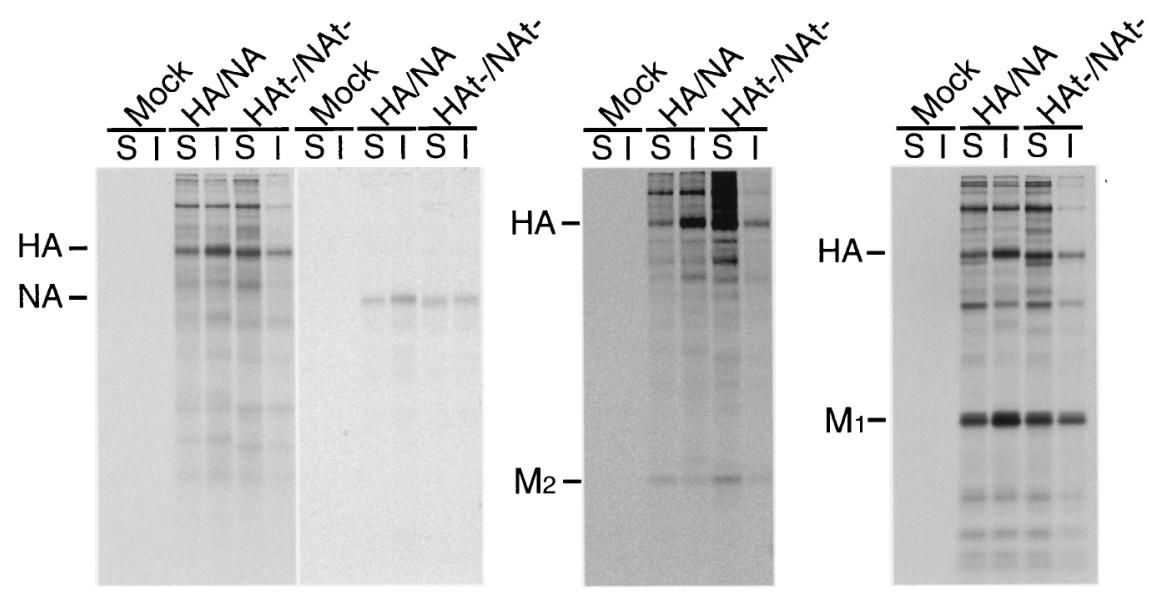

D

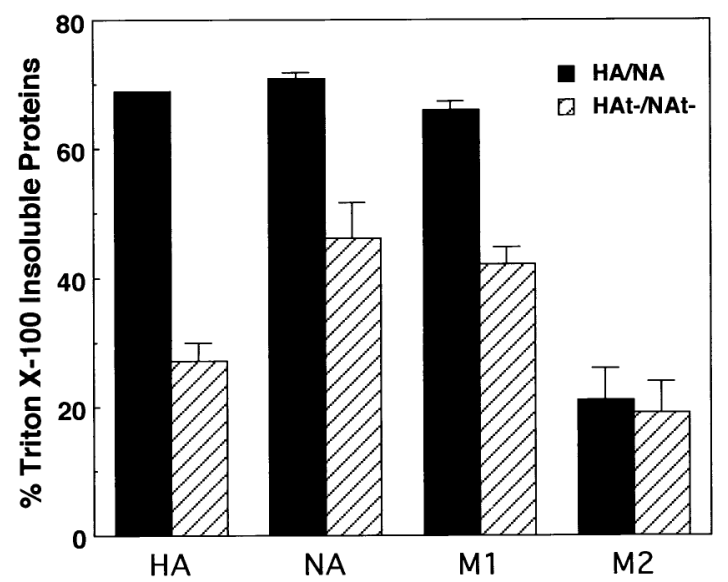

FIG. 1. TX-100 solubility of membrane proteins in HA/NA and HAt-/NAt- virus-infected MDCK cells. Influenza virus-infected MDCK cells were pulse-labeled with $\left[{ }^{35} \mathrm{~S}\right]$-Promix, cell surfaces were biotinylated, cells were extracted with $1 \% \mathrm{TX}-100$, and soluble (S) and insoluble (I) fractions were separated by centrifugation. Proteins were immunoprecipitated, biotinylated proteins were recovered with streptavidin-Sepharose beads, and polypeptides were analyzed by SDS-PAGE. (A) Biotinylated HA and NA; (B) biotinylated HA and $\mathrm{M}_{2} ;$ (C) total $\mathrm{HA}$ and $\mathrm{M}_{1}$ immunoprecipitated using anti-A/Udorn/72 influenza virus serum; (D) quantitation of TX-100-insoluble HA, NA, $\mathrm{M}_{1}$, and $\mathrm{M}_{2}$ proteins (data averaged from two independent experiments).

ine if deletion of the influenza virus HA and NA cytoplasmic tails affected raft association, polarized MDCK cells were infected with HA/NA or HAt-/NAt - virus. In addition to the cytoplasmic tail deletion, HAt $-/ \mathrm{NAt}-$ virus also contains a cysteine 555-to-methionine $\left(\mathrm{Cys}_{555} \mathrm{Met}\right)$ mutation in $\mathrm{HA}$ that eliminates the palmitoylation site present in the TM domain. To examine properties of plasma membrane-expressed viral membrane proteins, infected cells were metabolically labeled, cell surface-expressed proteins were biotinylated, cells were extracted with $1 \% \mathrm{TX}-100$ at $4^{\circ} \mathrm{C}$, and soluble and insoluble fractions were separated by centrifugation. Proteins were immunoprecipitated, and biotinylated molecules were recovered by using streptavidin-Sepharose. As shown in Fig. 1A, whereas HA and NA were localized predominantly in DIGs (HA and $\mathrm{NA}, \sim 70 \%$ insoluble), HAt - and NAt - showed an altered association with DIGs (HA, 28\% insoluble; NA, $45 \%$ insoluble). Previously, we have shown that the third influenza virus-specific integral membrane protein, the $\mathrm{M}_{2}$ ion channel protein, was soluble after $0.5 \%$ TX-100 extraction of wt influenza virus-infected cells (67). As shown in Fig. 1B, $\mathrm{M}_{2}$ was largely excluded from DIGs ( $\sim 20 \%$ insoluble) whether ex- pressed from HA/NA or HAt-/NAt- virus. The influenza virus $\mathrm{M}_{1}$ protein, a peripheral membrane protein, has been shown previously to become increasingly insoluble in TX-100 after a pulse-label with kinetics that parallel the TX-100 insolubility of HA $(57,67)$. Examination of total cell-expressed HA and $\mathrm{M}_{1}$ proteins by immunoprecipitation of TX-100-soluble and -insoluble proteins indicated that $\mathrm{M}_{1}$ protein was largely TX-100 insoluble in HA/NA virus-infected cells but became more soluble in HAt-/NAt - virus-infected cells (Fig. 1C and D).

To confirm the expected properties of DIGs in our system, we extracted biotinylated influenza virus-infected cells with TX-100 and performed flotation sucrose density gradient centrifugation. As shown in Fig. 2, a significant portion of cell surface-expressed HA (43\%) and NA $(68 \%)$ floated to the light gradient fractions, whereas the bulk of HAt- (97\%) and NAt- $(79 \%)$ was in the dense loading fractions. Taken together, these data suggest that the lack of an HA and NA cytoplasmic tail greatly affects the association of the proteins, as well as the $\mathrm{M}_{1}$ protein, with DIGs in virus-infected cells. 
HA/NA

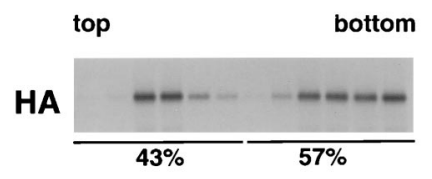

NA

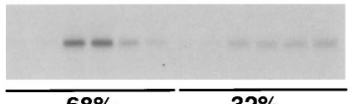

$68 \%$

$32 \%$

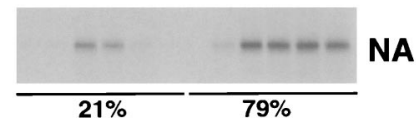

FIG. 2. Reduced DIGs association of HAt - and NAt - in virus-infected MDCK cells. HA/NA or HAt-/NAt - virus-infected MDCK cells were pulselabeled with $\left[{ }^{35} \mathrm{~S}\right]$-Promix, surface biotinylated, and extracted with TX-100. The lysate was then loaded at the bottom of a flotation sucrose density gradient and subjected to equilibrium centrifugation. The gradient was fractionated from the top, fractions were immunoprecipitated, biotinylated HA or NA was recovered by using streptavidin-Sepharose beads, and biotinylated polypeptides were analyzed by SDS-PAGE. The percentages of DIG-associated (top five fractions) and non-DIG-associated (bottom five fractions) proteins are indicated beneath the gels.

Diminished raft association is an intrinsic property of HAt - and NAt-. The association of cell surface-expressed HAt - and NAt - with DIGs in BHK cells was examined, as BHK cells are not polarized but contain DIGs (53). BHK cells were infected with influenza virus HA/NA, HAt-/NA, HA/ $\mathrm{NAt}-$, or HAt-/NAt- . To investigate if the solubility properties of the viral integral membrane proteins is an intrinsic property of the proteins, DIG association of $\mathrm{HA}, \mathrm{NA}, \mathrm{M}_{2}$, and cytoplasmic tail-altered HA and NA was examined when the proteins were expressed from cDNAs using plasmid vectors. Infection with VSV or transfection with a plasmid expressing the VSV G glycoprotein and examination of the properties of the $\mathrm{G}$ glycoprotein, a protein known not to associate with DIGs (4), was used as a control. Infected or transfected BHK cells were metabolically labeled, cell surfaces were biotinylated, TX-100-soluble and -insoluble fractions were obtained, proteins were immunoprecipitated, and biotinylated proteins were recovered using streptavidin-Sepharose followed by separation of polypeptides by SDS-PAGE. As shown in Fig. 3, whether expressed from influenza virus or from cDNA, HAtshowed markedly reduced association with DIGs compared to HA. For NAt - the reduction in DIG association compared to NA was not as large as for HAt - but was still readily detected. The $\mathrm{M}_{2}$ integral membrane protein was found almost exclusively in the TX-100-soluble fraction as was VSV G protein. Expression of $\mathrm{HA} \mathrm{C/t-}$, an HA that lacks a cytoplasmic tail but which retains the palmitoylated TM domain $\mathrm{Cys}_{555}$, did not show the large decrease in TX-100 insolubility found with HAt - (which contains the $\mathrm{Cys}_{555}$ Met mutation), suggesting that addition of palmitate at this position affects raft association. Interestingly, we noted in HA/NAt - virus-infected cells that the presence of NAt - reduced the association of HA with DIGs ( $\sim 40 \%$ HA insoluble) compared to HA in HA/NA virusinfected cells $(\sim 72 \%$ insoluble $)$, suggesting that in virus-infected cells there is a linkage effect of HA with NA at the plasma membrane with respect to DIG association, most likely due to the formation of sites of assembly of budding virions. In contrast, raft association of NA was not altered in the presence of HAt-. In aggregate, the data obtained from BHK cells mirror those obtained with polarized MDCK cells; they indicate that deletion of the HA and NA cytoplasmic tails greatly reduces the association of these glycoproteins with DIGs and

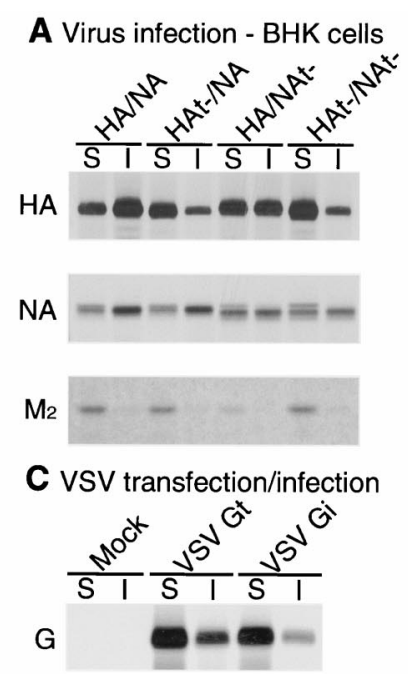

B cDNA expression - BHK cells

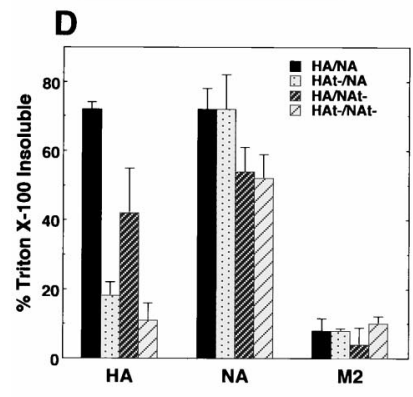

E
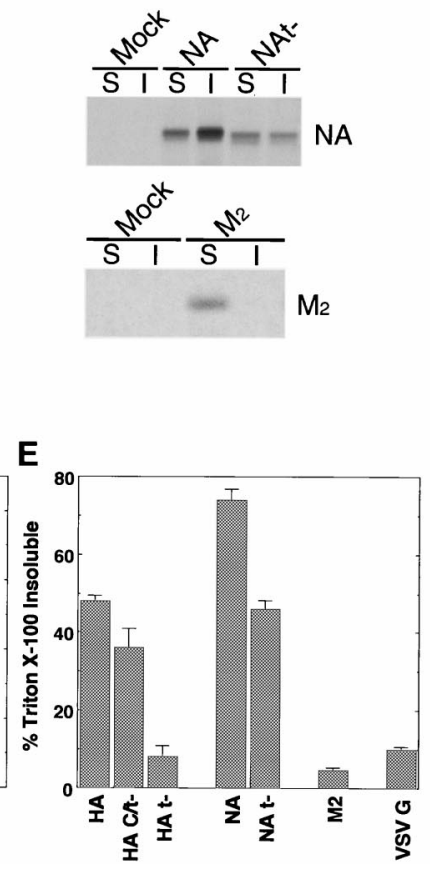

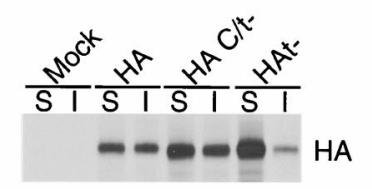

FIG. 3. TX-100 solubility of membrane proteins in BHK cells infected with HA/NA, HAt - /NA, HA/NAt - , and HAt - /NAt - . Virus-infected or plasmidtransfected BHK cells were pulse-labeled with $\left.{ }^{35} \mathrm{~S}\right]$-Promix, cell surfaces were biotinylated and extracted with $1 \%$ TX-100, and soluble (S) and insoluble (I) fractions were separated by centrifugation. Proteins were immunoprecipitated, surface biotinylated proteins were recovered with streptavidin-Sepharose beads, and polypeptides were analyzed by SDS-PAGE. (A) Surface HA, NA, and $\mathrm{M}_{2}$ in virus-infected BHK cells; (B) surface HA, NA, and $\mathrm{M}_{2}$ in plasmid-transfected BHK cells; (C) surface G protein from VSV-infected (VSV Gi) and VSV G cDNA-transfected (VSV Gt) BHK cells; (D) quantification of TX-100-insoluble $\mathrm{HA}, \mathrm{NA}$, and $\mathrm{M}_{2}$ proteins in virus-infected BHK cells; (E) quantification of TX-100-insoluble HA, NA, $\mathrm{M}_{2}$, and G proteins expressed from cDNAs. Panels $\mathrm{D}$ and $\mathrm{E}$ represent the average data from two independent experiments.

confirm that cell surface-expressed $\mathrm{M}_{2}$ integral membrane protein does not associate with DIGs.

Palmitoylation of $\mathrm{HA}$ and raft association in virus-infected cells. The data shown in Fig. $3 \mathrm{~B}$ indicated that plasmid-expressed $\mathrm{HA} \mathrm{C} / \mathrm{t}-$ in $\mathrm{BHK}$ cells had a greater association with DIGs $(\sim 37 \%)$ than HAt - $(8 \%)$. The difference between HA $\mathrm{C} / \mathrm{t}-$ and HAt - is that $\mathrm{HA} \mathrm{C} / \mathrm{t}-$ is palmitoylated at $\mathrm{Cys}_{555}$ whereas HAt - contains a $\mathrm{Cys}_{555} \mathrm{Met}$ mutation. Examination of the DIG association of HA containing various mutations at the three palmitoylation sites (cysteine residues 555, 562, and 565 ) indicated that HA requires three palmitoylated cysteine residues for DIG association (38). To examine the relationship of HA palmitate modification and HA DIG association in the context of a virus infection, MDCK cells were infected with viruses that contain mutations at the three sites for palmitoylation (22). It was observed that elimination of one (viral mutants CAC, CCA), two (viral mutant CAY), or three (viral mutant MAY) sites for palmitoylation decreased DIG association (Fig. 4). However, a virus (MAY) expressing HA lacking palmitoylation showed $48 \%$ DIG association, and the equivalent virus that lacked a cytoplasmic tail showed $35 \%$ DIG 


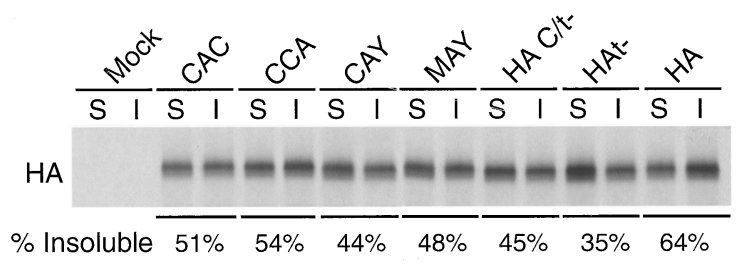

FIG. 4. Palmitoylation and the cytoplasmic tail of HA contribute to its resistance to TX-100 extraction. (A) MDCK cells were infected with various influenza A viruses harboring the indicated mutations in HA. TX-100-soluble and -insoluble surface HA proteins were analyzed as described in the legend to Fig. 1. (B) Quantification of TX-100-insoluble HA proteins (data averaged from two independent experiments).

association. NA DIG association in the context of the palmitate addition mutants was not examined. Taken together, the data suggest that both the cytoplasmic tail and the addition of palmitate are involved in association of HA with DIGs.

$M_{1}$ protein association with DIGs depends on the presence of viral glycoprotein cytoplasmic tails. The $M_{1}$ protein in influenza virus-infected cells becomes insoluble to TX-100 with kinetics that parallel HA becoming TX-100 insoluble (67). Furthermore, the data shown in Fig. 1C suggest that the presence of the HA and NA cytoplasmic tails may promote the association of $\mathrm{M}_{1}$ with DIGs. To examine further the possible association of $\mathrm{M}_{1}$ protein with DIGs, TX-100 cell lysates were subjected to analysis by flotation gradients. As shown in Fig. $5 \mathrm{~A}$, in HA/NA virus-infected cells a large fraction $(60 \%)$ of $\mathrm{M}_{1}$ protein was found together with HA in the light-density DIG fractions, whereas in HAt-/NAt - virus-infected cells very little $\mathrm{M}_{1}$ protein (10\%) (or HAt-) was found in the light-density fractions. Thus, the flotation of $\mathrm{M}_{1}$ protein on the gradients argues against the possibility that this fraction of the $\mathrm{M}_{1}$ protein was TX-100 insoluble because it was associated with the cytoskeleton. The association of $\mathrm{M}_{1}$ with DIGs is a property of $M_{1}$ in virus-infected cells, as when $M_{1}$ protein was expressed from cDNA, DIG association was not observed (67). Coexpression of $\mathrm{M}_{1}$ with $\mathrm{HA}, \mathrm{NA}$, and $\mathrm{M}_{2}$ proteins also did not cause TX-100 insolubility of $\mathrm{M}_{1}$ protein (67), but this negative result may be due to expression levels lower than those found in virus-infected cells or the need for assembly of viral nucleocapsids. To test further that the TX-100-insoluble $\mathrm{M}_{1}$ protein was associated with rafts, cholesterol was extracted from infected cell membranes to abolish the resistance to TX-100 solubilization of raft proteins. Influenza virus-infected and VSV-infected BHK cells were treated with lovastatin-mevalonate (to inhibit cholesterol biosynthesis) with or without addition of methyl- $\beta$-cyclodextrin (to remove any remaining cholesterol from membranes) (25). Viral protein synthesis levels were lower, presumably due to the effect of the treatment (Fig. 5). Confirming results found previously (53), HA became TX100 soluble and the solubility of VSV G protein was unchanged on depletion of cholesterol (Fig. 5). The influenza virus $\mathbf{M}_{1}$ protein became significantly more soluble in TX-100 on cholesterol depletion, supporting the notion that some of the $\mathrm{M}_{1}$ protein in HA/NA influenza virus-infected cells is associated directly or indirectly with DIGs (Fig. 5).

Deletion of the cytoplasmic tails of HA and NA do not affect apical targeting. Sphingolipid- and cholesterol-containing rafts have been proposed to be important for apical transport in polarized epithelial cells (55). Wild-type HA, NA, and $\mathrm{M}_{2}$ are expressed at the apical surface of polarized cells $(19,24,49)$. Previous studies indicated that alteration of residues in the TM domains of HA and NA can affect both DIG association and apical targeting, although the correlation was not absolute (28,

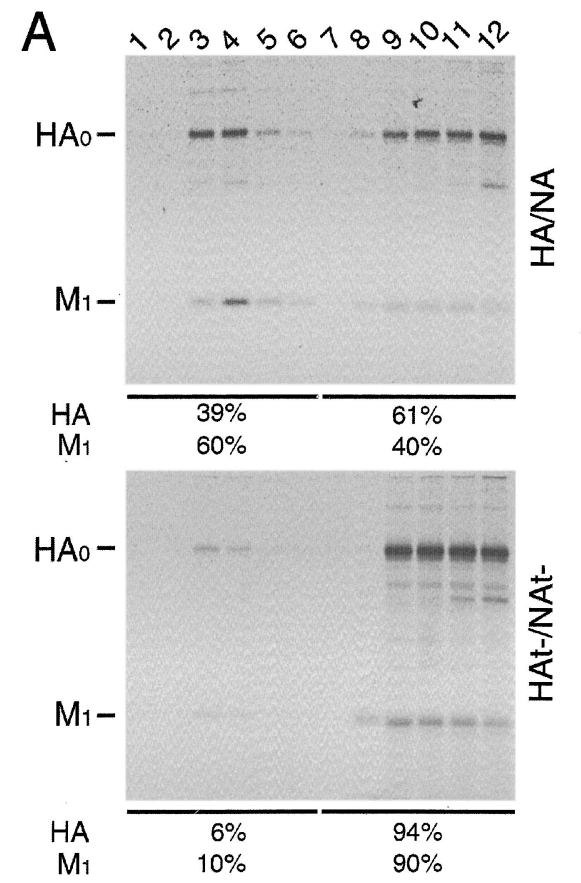

B
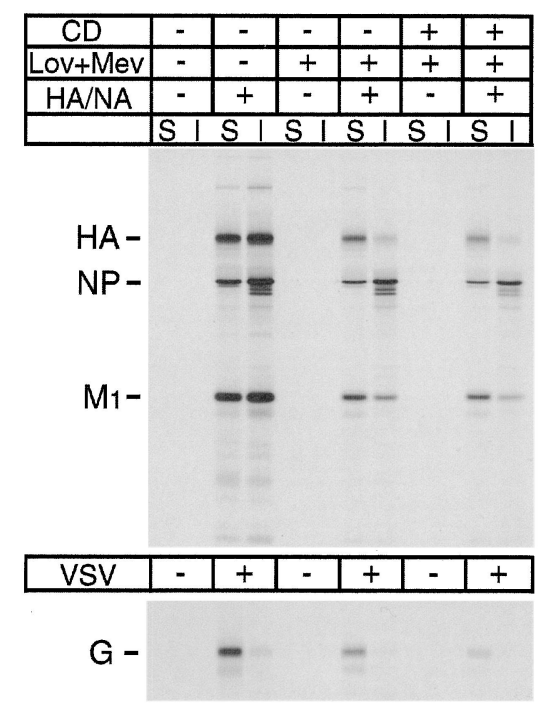

FIG. 5. The TX-100 insolubility of $\mathrm{M}_{1}$ protein in influenza virus-infected cells. (A) HA/NA and HAt-/NAt - virus-infected MDCK cells were subjected to TX-100 extraction and flotation gradient treatment as described in the legend to Fig. 2. Fractions were taken from the top and immunoprecipitated with goat sera with specificity for HA and $\mathrm{M}_{1}$, and polypeptides were analyzed by SDS-PAGE. (B) BHK cells were untreated or treated with lovastatin-mevalonate (Lov+ Mev) and, where indicated, with methyl- $\beta$-cyclodextrin (CD). Cell were then infected with HA/NA influenza virus or VSV, pulse-labeled with $\left[{ }^{35} \mathrm{~S}\right]-\mathrm{Promix}$, and extracted with $1 \%$ TX-100 at $4{ }^{\circ} \mathrm{C}$. Soluble (S) and insoluble (I) fractions were separated by centrifugation and immunoprecipitated, and polypeptides were analyzed by SDS-PAGE. 

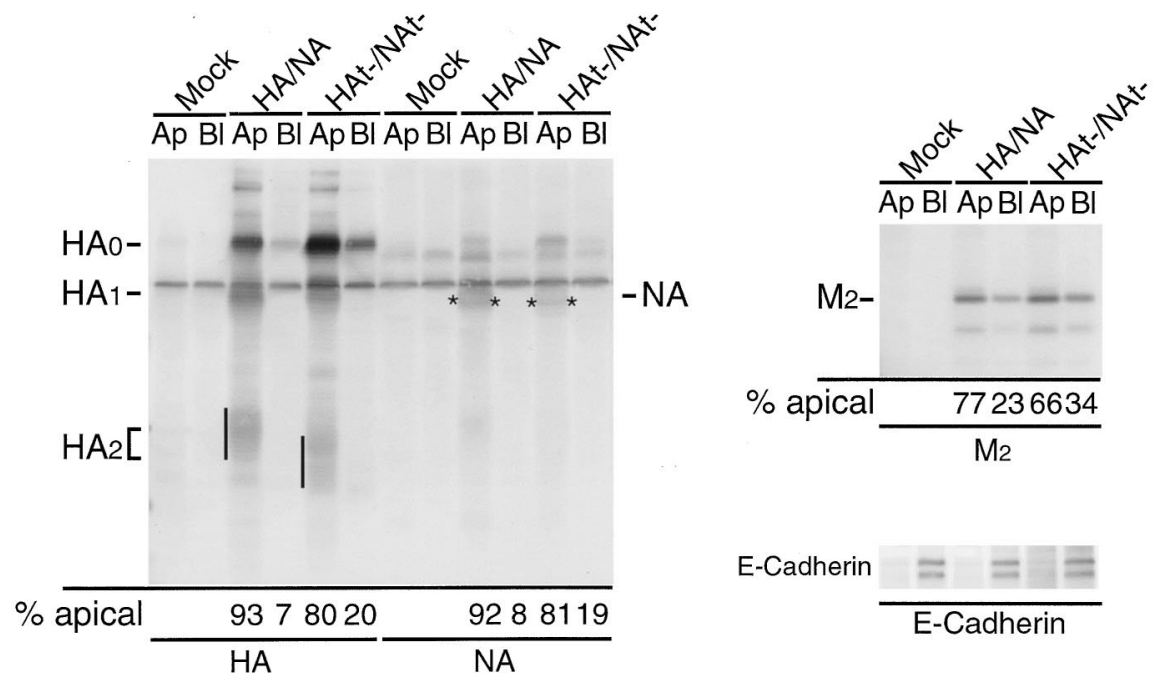

FIG. 6. Deletion of the cytoplasmic tails of HA and NA does not affect their transport to the apical cell surface. Polarized MDCK cells grown in Transwell inserts were infected with the indicated virus, and cell surfaces were biotinylated from either the apical (Ap) or the basolateral (Bl) side at $5 \mathrm{~h}$ p.i. The proteins of interest were immunoprecipitated, separated by electrophoresis, blotted to PVDF membranes, and detected by ECF blot assay. Quantification of the data is shown beneath the blots. The partial cleavage of $\mathrm{HA}_{0}$ reflects the $\mathrm{A} / \mathrm{WSN} / 33 \mathrm{NA}$-mediated cleavage of $\mathrm{A} / \mathrm{Udorn} / 72 \mathrm{HA}$ by residual plasminogen in the medium (14). No exogenous trypsin was added. Asterisks indicates NA polypeptide.

34, 53). Thus, given the altered DIG association of HA and NA lacking their cytoplasmic tails when expressed in influenza virus-infected cells, we examined the extent of apical surface expression of the viral integral membrane proteins, HA, NA, and $\mathrm{M}_{2}$ in HAt - /NAt - virus-infected cells. Polarized MDCK cells grown on filters were infected with $\mathrm{HA} / \mathrm{NA}$ or $\mathrm{HAt}-/$ NAt - virus, and the apical or basolateral cell surfaces were biotinylated. HA, NA, $\mathrm{M}_{2}$ species, and E-cadherin (as a control for a basolaterally expressed protein) were immunoprecipitated; polypeptides were separated by SDS-PAGE and transferred to a PDVF membrane. Biotinylated species were detected using streptavidin-alkaline phosphatase. As shown in Fig. 6, deletion of the cytoplasmic tail of HA or NA did not cause a major alteration in apical membrane targeting of the viral integral membrane protein $\mathrm{HA}, \mathrm{NA}$, or $\mathrm{M}_{2}$. Thus, apical transport and association with DIGs is uncoupled for HAt-, $\mathrm{NAt}-$, and $\mathrm{M}_{2}$ proteins.

To explore further the linkage of apical expression and raft association in polarized cells for natural proteins, in contrast to laboratory-generated mutants, we examined the expression of the influenza $\mathrm{C}$ virus HEF. HEF was expressed in influenza $\mathrm{C}$ virus-infected MDCK cells or expressed transiently from cDNA in HeLa-T4 cells. Surface-expressed $\mathrm{HEF}_{0}$ was cleaved to $\mathrm{HEF}_{1}$ and $\mathrm{HEF}_{2}$ by addition of exogenous trypsin. It was observed that HEF remained TX-100 soluble (97\%) in virusinfected and cDNA-transfected cells and yet was expressed almost exclusively at the apical surface of polarized MDCK cells (Fig. 7). These findings add further support to the notion that glycoproteins do not have to be associated with rafts to be targeted apically.

Role of raft association in selective incorporation of influenza A virus integral membrane proteins: incorporation of $\mathrm{HA}$ and NA and exclusion of $\mathbf{M}_{2}$. The influenza virus integral membrane proteins $\mathrm{HA}, \mathrm{NA}$, and $\mathrm{M}_{2}$ are all abundantly expressed in virus-infected cells and yet only 5 to $15 \mathrm{M}_{2}$ tetramers are found on average per virion, in comparison to approximately 500 HA trimers (66). To test the hypothesis that $M_{2}$ is largely excluded from virions because, unlike HA and NA, it is not localized to rafts, we examined the amount of $\mathrm{M}_{2}$ con- tained in $\mathrm{HA} / \mathrm{NA}, \mathrm{HAt}-/ \mathrm{NA}, \mathrm{HA} / \mathrm{NAt}-$, and HAt - /NAt virions by immunoblotting of purified virion preparations. The absence of the HA cytoplasmic tail alone did not have an effect on $\mathrm{M}_{2}$ incorporation into virions, and the absence of the NA cytoplasmic tail caused a small increase in $\mathrm{M}_{2}$ incorporation into virions (Fig. 8). However, it was observed that for HAt-/ $\mathrm{NAt}-$ virions the amount of $\mathrm{M}_{2}$ incorporated into the particles increased considerably relative to HA or NA. Taken together, the increased amounts of $\mathrm{M}_{2}$ in $\mathrm{HAt}-/ \mathrm{NAt}-$ virions correlate with the DIG association of $\mathrm{HAt}-$, NAt - , and $\mathrm{M}_{2}$ proteins. Thus, these observations provide an explanation for the inclusion of HA and NA versus the exclusion of $\mathrm{M}_{2}$ into a budding wt virion.

TX-100 solubility of $\mathrm{HA}$ and $\mathrm{M}_{1}$ protein in purified virions. It has been shown previously that HA is insoluble in $1 \% \mathrm{TX}$ 100 in purified influenza virions (53). To examine the TX-100

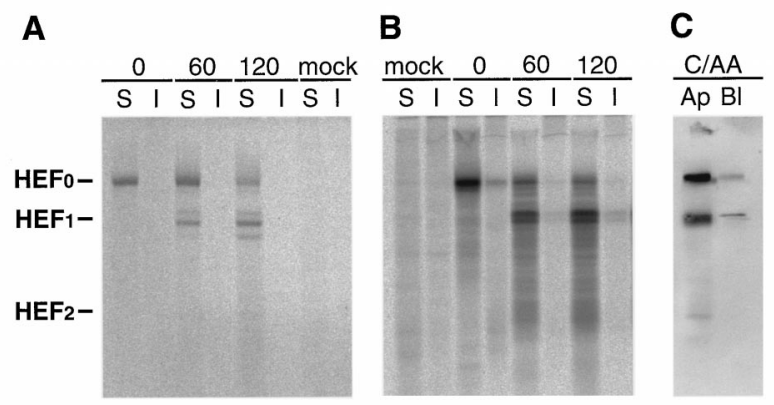

FIG. 7. The influenza $\mathrm{C}$ virus $\mathrm{HEF}$ protein is $\mathrm{TX}-100$ soluble and transported to the apical surface. Influenza C/Ann Arbor/1/50 virus-infected MDCK cells (A) or HEF cDNA-transfected HeLa-T4 cells (B) were pulse-labeled with $\left[{ }^{35} \mathrm{~S}\right]-$ Promix and after the indicated chase times incubated with TPCK-trypsin (15 $\mu \mathrm{g} / \mathrm{ml}$ ) for $10 \mathrm{~min}$ at $37^{\circ} \mathrm{C}$ to cleave cell surface-expressed $\mathrm{HEF}_{0}$ to $\mathrm{HEF}_{1}$ and $\mathrm{HEF}_{2}$. Cells were extracted with $1 \% \mathrm{TX}-100$, soluble (S) and insoluble (I) fractions were separated by centrifugation, HEF was immunoprecipitated, and polypeptides were analyzed by SDS-PAGE. (C) The apical (Ap) and basolateral (Bl) transport of HEF in infected MDCK cells was analyzed as described in the legend to Fig. 6. 

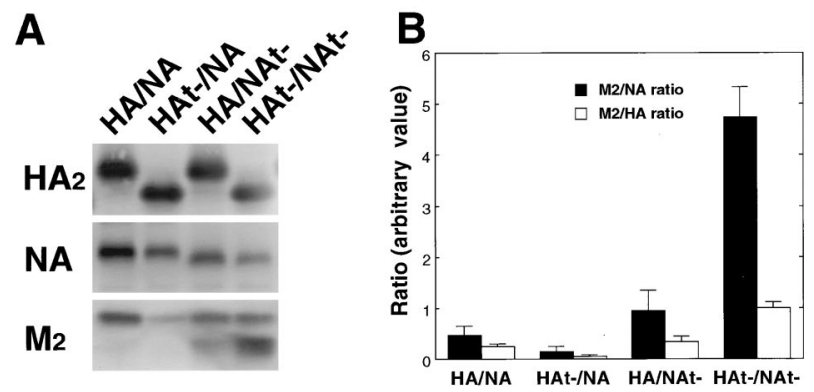

FIG. 8. Incorporation of $\mathrm{M}_{2}$ into $\mathrm{HA}$ and NA cytoplasmic tail-altered influenza viruses. Virions were purified on sucrose gradients, $\mathrm{N}$-linked carbohydrate chains were digested with peptidyl $N$-glycosidase F, and polypeptides were separated by SDS-PAGE and blotted to PVDF membranes. HA, NA, and $\mathrm{M}_{2}$ proteins were detected with specific antibodies using an ECF Western blot assay (Pharmacia Amersham Biotech) (A). Quantification of the data was performed using ImageQuant software (Molecular Dynamics), and $\mathrm{M}_{2} / \mathrm{NA}$ and $\mathrm{M}_{2} / \mathrm{HA}$ ratios were plotted (B). The faster-migrating species of $\mathrm{M}_{2}$ is a proteolytic product of $\mathrm{M}_{2}$ and was included in the quantification.

solubility of HA and NA in purified virions, HA/NA, HAt-/ $\mathrm{NA}, \mathrm{HA} / \mathrm{NAt}-$, and $\mathrm{HAt}-\mathrm{NAt}-$ virions were solubilized with different concentrations of TX-100, as the protein/lipid ratio is greatly changed in virions compared to virus-infected cells. It was found that whereas HA in wt virions (HA/NA) was $65 \%$ insoluble in $0.1 \%$ TX-100 (Fig. 9), HAt- was nearly entirely soluble in $0.1 \%$ TX-100 from either $\mathrm{HAt}-/ \mathrm{NA}$ or HAt - /NAt - virions. Again, a linkage effect on HA TX-100 solubility with NAt - was observed in HA/NAt - virions, as in these virions HA was solubilized by $0.1 \%$ TX-100. Concomitant with solubilization of HA by using $0.1 \%$ TX-100 for $\mathrm{HAt}-/ \mathrm{NA}, \mathrm{HA} / \mathrm{NAt}-$, and HAt-/NAt - viruses, $\mathrm{M}_{1}$ protein exhibited increased solubility. This was most pronounced for HA/NAt - but was also observed for HAt-/NA virus. For HAt - NAt - , an increased ratio of TX-100-soluble $\mathrm{M}_{1}$ protein compared to the ratio for HA/NA virus was observed, but HAt-/NAt - virions incorporate less $\mathrm{M}_{1}$ protein relative to NP than HAt - /NAt - and HA/NAt - virions (22). This may

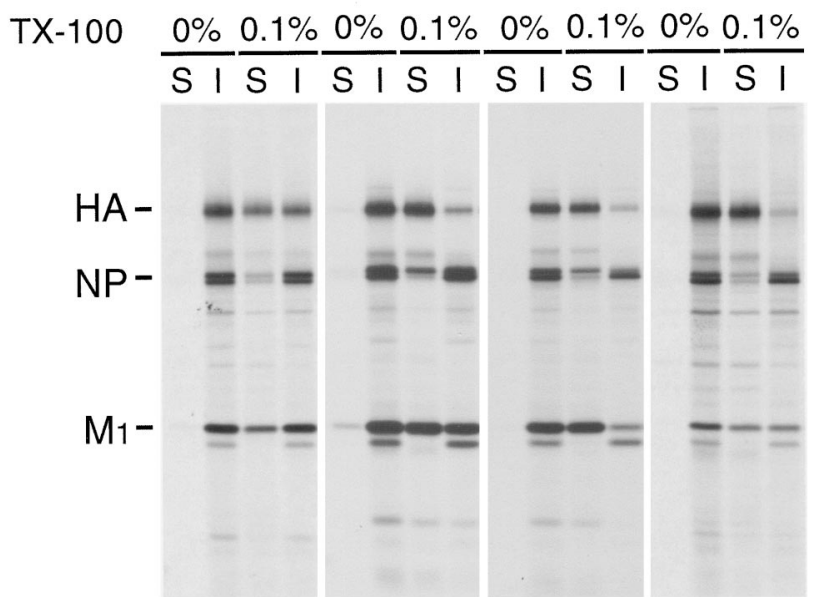

HA/NA HAt-/NA HA/NAt- HAt-/NAt-

FIG. 9. TX-100 solubility of HA and $\mathrm{M}_{1}$ protein in HA and NA cytoplasmic tail-altered influenza viruses. Purified MDCK cell-grown ${ }^{35} \mathrm{~S}$-labeled influenza viruses as indicated were extracted with $0.1 \%$ TX-100 for $30 \mathrm{~min}$ at $4^{\circ} \mathrm{C}$. Soluble (S) and insoluble (I) fractions were separated by centrifugation, and polypeptides were analyzed by SDS-PAGE. complicate interpretation of the data, as a given fraction of $\mathrm{M}_{1}$ may always be associated with the RNP fraction. Nonetheless, the data support the collective observations that both in virusinfected cells and in virions, the presence of the spike glycoprotein cytoplasmic tails causes a significant fraction of the $\mathbf{M}_{1}$ to be associated, directly or indirectly, with DIGs and that in the absence of the cytoplasmic tails, $M_{1}$ protein association with DIGs is significantly reduced.

Analysis of the lipid composition of spike glycoprotein cytoplasmic tail-altered influenza viruses. Analysis of influenza virus grown in BHK cells has shown that influenza virion membranes contain more cholesterol than those of VSV or Semliki Forest virus (52). A greater amount of cyclodextrin was required to extract the cholesterol from influenza virions than from VSV, further suggesting a higher cholesterol content. Biochemical analysis of the lipids of virions compared to those of BHK cell membranes indicated that influenza virions contained a higher cholesterol and sphingomyelin content than BHK cell membranes or of VSV membranes (52). These data suggest that influenza virions bud from DIG domains. Thus, the lipid composition of the spike glycoprotein cytoplasmic tail-altered viruses was determined. Virions were grown in embryonated chicken eggs, where the virus grows in the endodermal cells lining the allantoic sac (5). The endoderm lining the allantoic cavity may proliferate to two or three layers of cells in some places while remaining only one layer thick in others (50). Ideally, interpretation of the data would be simplest if the four viruses were grown in MDCK or BHK cells. However, the poor growth of HAt-/NAt - in tissue culture precluded obtaining the amount of virions necessary for lipid analysis.

Viral lipids from purified HA/NA, HAt-/NA, HA/NAt-, and $\mathrm{HAt}-/ \mathrm{NAt}-$ virions (3.2 $\mathrm{mg}$ of protein) were extracted and analyzed by HPTLC (Fig. 10), and the amount of each lipid was quantified, normalized to the amount of viral protein, and compared to the lipid composition of TX-100-insoluble vesicles derived from MDCK cells (4) (Table 1). A raft index was calculated by dividing raft-related lipids (cholesterol, sphingomyelin, and cerebrosides) with non-raft-related lipids (phospholipids and triglycerides). As shown in Table 1, HA/NA virus was found to be cholesterol and sphingomyelin rich, similar to the composition of DIGs. Deletion of the cytoplasmic tail of either HA or NA (HAt-/NA or HA/NAt-) did not change greatly the lipid composition of the virions from that of HA/NA virus, again suggesting a linkage between the presence of a single glycoprotein cytoplasmic tail and DIG association. However, for HAt-/NAt - , the cholesterol and sphingomyelin concentrations were lower and the triglyceride concentration was increased. The raft index for HA/NA was 1.68, versus 1.16 for HAt - /NAt - virions. Thus, these data are consistent with $\mathrm{HA} / \mathrm{NA}$ virions budding predominantly from raft microdomains, whereas HAt - /NAt - virus may no longer bud strictly from the raft microdomains.

\section{DISCUSSION}

The cytoplasmic tails of HA and NA are important for influenza virus assembly and budding $(21-23,68)$. It has been suggested that sphingolipid- and cholesterol-rich membrane microdomain rafts are essential for apical targeting and influenza virus budding $(52,55)$. Thus, it was of interest to investigate the relationship of the cytoplasmic tail-altered spike glycoproteins with sphingolipid- and cholesterol-rich membrane microdomain rafts.

Influenza virus HA and NA have been shown previously to associate with DIGs (53). Deletion of the cytoplasmic tails of 


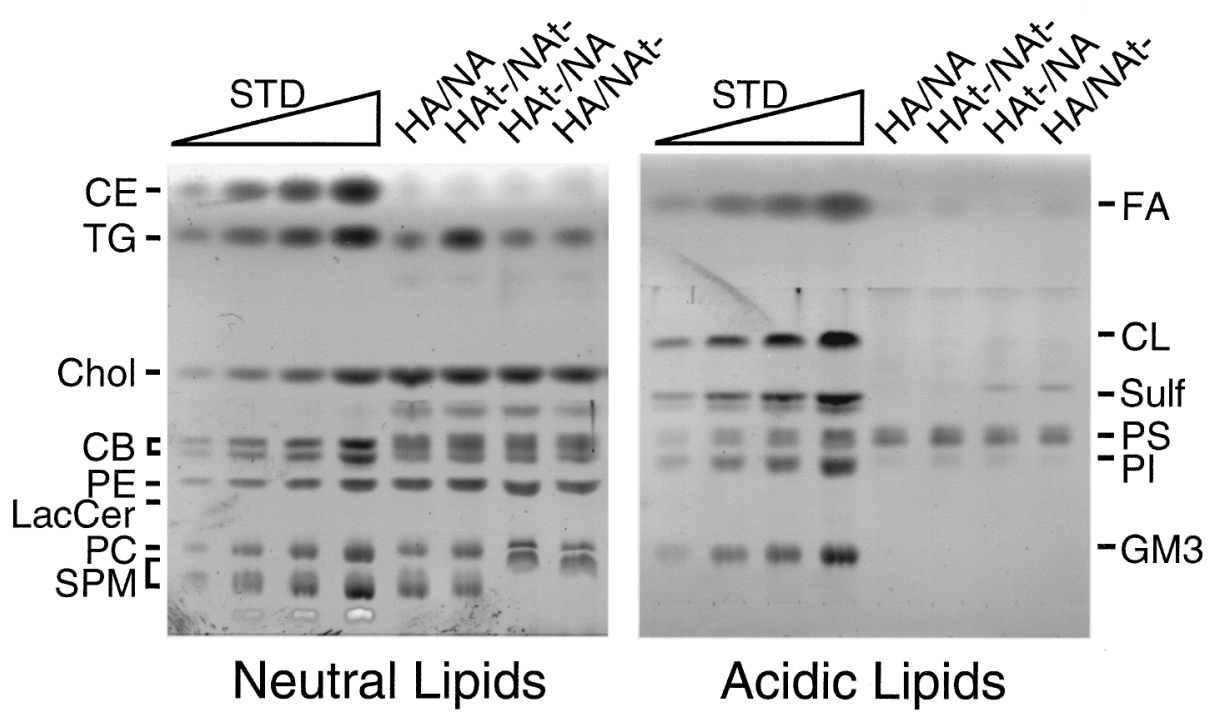

FIG. 10. Lipid composition analysis of HA and NA cytoplasmic tail-altered influenza viruses. Lipids were extracted from purified HA/NA, HAt-/NA, HA/NAt-and HAt - /NAt - virions grown in embryonated eggs as described in Materials and Methods. Lipids were analyzed by HPTLC. Wedges: $1,3,5$, and $10 \mu g$, in the four lanes, respectively, of each standard lipid. The experiment was done in duplicate, and representative TLC plates are shown. CE, cholesteryl ester; TG, triglyceride; Chol, cholesterol; CB, cerebroside; PE, phosphotidylethanolamine; LacCer, lactosyl ceramide; PC, phosphotidylcholine; SPM, sphingomyelin; FA, fatty acids; CL, cardiolipin; Sulf, sulfatides; PS, phosphotidylserine; PI, phosphotidylinositol.

HA and NA causes a reduction in DIG association that is an intrinsic property of each glycoprotein. Nonetheless, in influenza virus-infected cells the deletion of the NA cytoplasmic tail leads to a reduction in the DIG association of HA. This tail/ DIG linkage phenomenon may be a reflection on the process of virus assembly. The tail/DIG linkage phenomenon also extends to virions where HA was found to be TX-100 soluble in HAt - /NA and HA/NAt - virions. The morphology of the dou- ble cytoplasmic tail deletion virus HAt-/NAt - is grossly altered from that of standard HA/NA virus, and HAt-/NAtincorporates $\mathrm{M}_{1}$ protein inefficiently and has defective genome packaging and reduced infectivity $(22,68)$. Virus lacking an HA cytoplasmic tail deletion (HAt-/NA) is morphologically very similar to HA/NA virus, whereas viruses lacking the NA cytoplasmic tail (HA/NAt-) show small extents of morphological deformations $(21,22)$. These observations led to the hy-

TABLE 1. Lipid composition of influenza A virions

\begin{tabular}{|c|c|c|c|c|c|}
\hline \multirow[b]{2}{*}{ Lipid } & \multicolumn{5}{|c|}{ Mol\% lipid composition } \\
\hline & HA/NA & $\mathrm{HAt}-/ \mathrm{NA}$ & HA/NAt- & $\mathrm{HAt}-/ \mathrm{NAt}-$ & $\begin{array}{c}\text { TX-100-resistant } \\
\text { vesicles }^{a}\end{array}$ \\
\hline \multicolumn{6}{|l|}{ Phospholipids } \\
\hline Phosphatidylethanolamine & $15.85 \pm 0.47$ & $17.75 \pm 0.12$ & $16.65 \pm 0.37$ & $16.09 \pm 0.25$ & 17.6 \\
\hline Phosphatidylcholine & $6.71 \pm 0.90$ & $9.03 \pm 1.07$ & $6.90 \pm 0.42$ & $9.38 \pm 0.70$ & 12.4 \\
\hline Phosphatidylserine & $11.65 \pm 0.34$ & $10.10 \pm 0.24$ & $11.27 \pm 0.08$ & $10.76 \pm 0.72$ & 2.2 \\
\hline Phosphatidylinositol & $0.67 \pm 0.75$ & $1.11 \pm 0.44$ & $0.55 \pm 0.45$ & $1.15 \pm 0.59$ & 2.7 \\
\hline Sphingomyelin & $9.11 \pm 1.30$ & $9.86 \pm 0.77$ & $10.61 \pm 0.26$ & $6.55 \pm 1.16$ & 11.1 \\
\hline Cholesterol & $43.97 \pm 0.71$ & $40.60 \pm 0.51$ & $39.17 \pm 0.89$ & $37.54 \pm 0.91$ & 32.7 \\
\hline Triglyceride & $2.49 \pm 0.32$ & $2.35 \pm 0.67$ & $3.73 \pm 0.71$ & $8.91 \pm 0.25$ & $\mathrm{ND}^{b}$ \\
\hline \multicolumn{6}{|l|}{ Neutral glycolipids } \\
\hline Cerebrosides & $9.55 \pm 0.25$ & $9.21 \pm 0.34$ & $11.12 \pm 0.18$ & $9.61 \pm 0.14$ & 7.6 \\
\hline Fossman antigen & ND & ND & ND & ND & 6.7 \\
\hline Lactosyl ceramide & $\mathrm{ND}$ & $\mathrm{ND}$ & ND & $\mathrm{ND}$ & 2.4 \\
\hline \multicolumn{6}{|l|}{ Acidic glycolipids } \\
\hline Sulfatides & ND & ND & ND & ND & 2.9 \\
\hline Gangliosides & ND & ND & ND & ND & 1.8 \\
\hline Raft index $(\mathrm{mol} / \mathrm{mol})^{c}$ & $1.68 \pm 0.02$ & $1.48 \pm 0.00$ & $1.56 \pm 0.06$ & $1.16 \pm 0.01$ & 1.87 \\
\hline
\end{tabular}

${ }^{a}$ Calculated from data published in reference 4.

${ }^{b} \mathrm{ND}$, not detected.

${ }^{c}$ Calculated by dividing raft-related lipids (cholesterol, sphingomyelin, and cerebrosides) with non-raft-related lipids (phospholipids and triglycerides). 
pothesis that the cytoplasmic tail of NA is more important for virus assembly than the HA cytoplasmic tail but that the cytoplasmic tails of HA and NA are so important for assembly that the information contained in these tails is partially redundant (22). Influenza A virus most likely buds from rafts (52), and thus the tail/DIG linkage phenomenon observed in virus-infected cells on deletion of a single cytoplasmic tail supports the hypothesis of dual redundancy of tail information.

The mechanism by which certain proteins are selected for rafts is not clearly understood. It is known that many but not all GPI-linked proteins are raft associated (38). However, for membrane-spanning proteins, the signal for raft incorporation is unknown. For some membrane-spanning proteins such as the linker molecule LAT, which is a critical substrate of the tyrosine kinases activated upon T-cell antigen receptor engagement, palmitoylation of the cytoplasmic tail is essential for raft association (69). Influenza virus NA cytoplasmic tail and TM domain do not contain a cysteine residue, and NA is thus not palmitoylated, but it is associated with rafts. It has been reported that HA requires all three of its palmitoylated cysteine residues for raft association when it is expressed from cDNA (38). However, in the context of an influenza virus infection, palmitoylation of HA contributes to association with DIGs, but the presence of an HA cytoplasmic tail is clearly an important factor. Furthermore, from cDNA expression of $\mathrm{HA} \mathrm{C} / \mathrm{t}-$, we observed that a single palmitate addition contributed to TX100 insolubility but palmitate addition at all three sites was not required for DIG association. Residues in the HA TM domain are important for raft association, as expression of glycoproteins with mutations in the middle of the TM domain show greatly reduced association with DIGs $(34,53)$. One possible explanation for the decrease in raft association on deletion of the HA or NA cytoplasmic tail is that the cytoplasmic tail alters the quaternary structure of the TM domain such that its association with specific lipids or other proteins is changed. Both the cellular tetraspanning membrane protein VIP17/MAL and annexin XIIIb have been implicated as being involved in determining the association of HA with lipid rafts $(6,10,11,39$, 48 ). It remains to be explored if the known interaction between HA and VIP17/MAL (48) is altered on deletion of the HA cytoplasmic tail.

The $\mathrm{M}_{2}$ ion channel protein was largely excluded from rafts; the finding that influenza A virus buds from rafts (52) provides an explanation for the low amount of $\mathrm{M}_{2}$ protein in virions compared to HA, given that both $\mathrm{M}_{2}$ and $\mathrm{HA}$ proteins are abundantly expressed at the plasma membrane $(31,66)$. Support for this notion is provided by finding that HAt-/NAtvirions incorporate a greater amount of $\mathrm{M}_{2}$ relative to $\mathrm{HA}$ or NA. This is consistent with the lipid analysis of HAt-/NAtvirions, which suggests that these virions do not bud strictly from the raft microdomains.

A link between the association of proteins with rafts and targeting to the apical surface of polarized cells has been made, in large part based on studies with influenza virus $\operatorname{HA}(2,6,29$, $34,48,55)$. However, it is also becoming evident that another signaling mechanism for apical targeting must exist, as several proteins that are not insoluble in TX-100 at $4^{\circ} \mathrm{C}$, such as bovine enteropeptidase (70), intestinal maltase-glucoamylase, and lactase-phlorizin hydrolase (8), are apically expressed. Moreover, the influenza $\mathrm{C}$ virus HEF glycoprotein is apically targeted but not associated with DIGs. In addition, the influenza $A$ virus $\mathbf{M}_{2}$ protein which is targeted to the apical surface of cells (19) is not associated with DIGs. Both HEF and $\mathrm{M}_{2}$ are palmitoylated on their cytoplasmic tails $(18,61,62)$ and yet are excluded from DIGs, suggesting that acylation itself does not always confer raft association. Furthermore, some mutations in the HA TM domain, although not affecting apical sorting, cause greatly reduced association of HA with DIGs (34). However, the detergent-insoluble membrane fraction that is isolated by the standard biochemical procedure might not be completely equivalent to the lipid rafts within cells; some proteins that may appear in the soluble fraction may be extracted from rafts during the procedure because they are not tightly bound to rafts (3).

Deletion of the HA and NA cytoplasmic tails in HAt-/ NAt - virus did not change apical targeting of HAt- and NAt - , yet the viruses show greatly reduced association with DIGs. Although the signals involved in basolateral targeting often depend on a discrete signal in the cytoplasmic tail of the protein, the signals for apical transport have remained more difficult to elucidate. Signals implicated in apical targeting include the TM domain $(28,53)$, possession of a GPI-membrane anchor $(2,35)$, and the presence of extracellular N-linked glycan moieties $(16,51)$ or O-linked carbohydrate moieties $(65)$. Interestingly, the influenza virus $\mathrm{M}_{2}$ protein lacks carbohydrate moieties, is not raft associated, and is apically targeted. Furthermore, models for apical sorting are complicated by findings such as the observation that HA, normally a apically targeted protein, is efficiently incorporated into VSV (27) (a virus that in polarized cells buds from the basolateral surface), and HA in these VSV envelopes is TX-100 soluble (52).

The influenza virus $\mathrm{M}_{1}$ protein associates with RNPs in the nucleus and is involved with the $\mathrm{NS}_{2}$ protein in the export of the RNPs from the nucleus $(37,44,63)$. A fraction of the pool of $\mathrm{M}_{1}$ protein also associates with cellular membrane fractions $(1,9,15,17,26,67)$, and it is generally believed that $M_{1}$ protein associates with the cytoplasmic tails of HA and NA. However, biochemical evidence to demonstrate these protein-protein interactions in living cells has been difficult to obtain $(9,26,67)$. In cells infected with standard HA/NA virus, a large fraction of the cytosolic $\mathrm{M}_{1}$ protein associates with DIGs. Furthermore, in purified virions, $M_{1}$ protein was largely TX-100 insoluble. However, in HAt-/NAt - virus-infected cells, the $\mathrm{M}_{1}$ protein association with DIGs was greatly reduced, and in virions lacking either the HA or NA cytoplasmic tail, the fraction of $\mathrm{M}_{1}$ protein that was TX-100 soluble was much larger than that found for HA/NA virus. The poor incorporation of $\mathrm{M}_{1}$ protein into HAt - NAt - virus makes interpretation of the data more complex, but one interpretation is that in HAt-/NAt - virions the bulk of the $M_{1}$ protein is derived from the $M_{1}$ pool associated with the RNPs and the $M_{1}$ protein derived from the membrane-associated pool is lacking from the virions. It is not known if the association of the $\mathrm{M}_{1}$ protein with DIGs is direct or indirect, but the data indicate it is aided by the presence of the spike glycoprotein cytoplasmic tails. A plausible scenario is that HA and NA coalesce into a raft and the HA and NA cytoplasmic tails help dock the $\mathrm{M}_{1}$ protein into a preassembly scaffold that could then interact with other $M_{1}$ protein subunits associated with the RNPs, thus facilitating the assembly of the virion components. In the absence of this scaffold budding is severely compromised, as observed by changes in viral protein and RNA composition of HAt-/NAt - virions and their altered morphology $(22,68)$. Thus, the data suggest that for influenza A virus, rafts serve as a site for concentrating viral proteins and promoting the production of infectious virus.

\section{ACKNOWLEDGMENTS}

This research was supported by Public Health Service research grant R37 AI-20201 from the National Institute of Allergy and Infectious Diseases. A.P. is an Associate and R.A.L. is an Investigator of the Howard Hughes Medical Institute. 


\section{REFERENCES}

1. Avalos, R. T., Z. Yu, and D. P. Nayak. 1997. Association of influenza virus NP and M1 proteins with cellular cytoskeletal elements in influenza virus-infected cells. J. Virol. 71:2947-2958.

2. Brown, D. A., B. Crise, and J. K. Rose. 1989. Mechanism of membrane anchoring affects polarized expression of two proteins in MDCK cells. Science 245:1499-1501.

3. Brown, D. A., and E. London. 1998. Functions of lipid rafts in biological membranes. Annu. Rev. Cell Dev. Biol. 14:111-136.

4. Brown, D. A., and J. K. Rose. 1992. Sorting of GPI-anchored proteins to glycolipid-enriched membrane subdomains during transport to the apical cell surface. Cell 68:533-544.

5. Burnet, F. M. 1941. Growth of influenza virus in the allantoic cavity of the chick embryo. Aust. J. Exp. Biol. Med. Sci. 19:291-295.

6. Cheong, K. H., D. Zacchetti, E. E. Schneeberger, and K. Simons. 1999. VIP17/MAL, a lipid raft-associated protein, is involved in apical transport in MDCK cells. Proc. Natl. Acad. Sci. USA 96:6241-6248.

7. Colman, P. M. 1989. Neuraminidase: enzyme and antigen, p. 175-218. In R. M. Krug (ed.), The influenza viruses. Plenum Press, New York, N.Y.

8. Danielsen, E. M. 1995. Involvement of detergent-insoluble complexes in the intracellular transport of intestinal brush border enzymes. Biochemistry 34: $1596-1605$.

9. Enami, M., and K. Enami. 1996. Influenza virus hemagglutinin and neuraminidase glycoproteins stimulate the membrane association of the matrix protein. J. Virol. 70:6653-6657.

10. Fiedler, K., T. Kobayashi, T. V. Kurzchalia, and K. Simons. 1993. Glycosphingolipid-enriched, detergent-insoluble complexes in protein sorting in epithelial cells. Biochemistry 32:6365-6373.

11. Fiedler, K., F. Lafont, R. G. Parton, and K. Simons. 1995. Annexin XIIIb: a novel epithelial specific annexin is implicated in vesicular traffic to the apical plasma membrane. J. Cell Biol. 128:1043-1053.

12. Friedrichson, T., and T. V. Kurzchalia. 1998. Microdomains of GPI-anchored proteins in living cells revealed by crosslinking. Nature 394:802-805.

13. Garcia-Sastre, A., and P. Palese. 1995. The cytoplasmic tail of the neuraminidase protein of influenza A virus does not play an important role in the packaging of this protein into viral envelopes. Virus Res. 37:37-47.

14. Goto, H., and Y. Kawaoka. 1998. A novel mechanism for the acquisition of virulence by a human influenza A virus. Proc. Natl. Acad. Sci. USA 95: 10224-10228.

15. Gregoriades, A., and B. Frangione. 1981. Insertion of influenza M protein into the viral lipid bilayer and localization of site of insertion. J. Virol. 40:323-328.

16. Gut, A., F. Kappeler, N. Hyka, M. S. Balda, H. P. Hauri, and K. Matter. 1998. Carbohydrate-mediated Golgi to cell surface transport and apical targeting of membrane proteins. EMBO J. 17:1919-1929.

17. Hay, A. J. 1974. Studies on the formation of the influenza virus envelope. Virology 60:398-418.

18. Holsinger, L. J., M. A. Shaughnessy, A. Micko, L. H. Pinto, and R. A. Lamb. 1995. Analysis of the posttranslational modifications of the influenza virus $\mathrm{M}_{2}$ protein. J. Virol. 69:1219-1225.

19. Hughey, P. G., R. W. Compans, S. L. Zebedee, and R. A. Lamb. 1992. Expression of the influenza A virus $\mathrm{M}_{2}$ protein is restricted to apical surfaces of polarized epithelial cells. J. Virol. 66:5542-5552.

20. Hunziker, W., C. Harter, K. Matter, and I. Mellman. 1991. Basolateral sorting in MDCK cells requires a distinct cytoplasmic domain determinant. Cell 66:907-920.

21. Jin, H., G. Leser, and R. A. Lamb. 1994. The influenza virus hemagglutinin cytoplasmic tail is not essential for virus assembly or infectivity. EMBO J. 13:5504-5515.

22. Jin, H., G. P. Leser, J. Zhang, and R. A. Lamb. 1997. Influenza virus hemagglutinin and neuraminidase cytoplasmic tails control particle shape. EMBO J. 16:1236-1247.

23. Jin, H., K. Subbarao, S. Bagai, G. P. Leser, B. R. Murphy, and R. A. Lamb. 1996. Palmitylation of the influenza virus hemagglutinin (H3) is not essential for virus assembly or infectivity. J. Virol. 70:1406-1414.

24. Jones, L. V., R. W. Compans, A. R. Davis, T. J. Bos, and D. P. Nayak. 1985. Surface expression of influenza virus neuraminidase, an amino-terminally anchored viral membrane glycoprotein, in polarized epithelial cells. Mol. Cell. Biol. 5:2181-2189.

25. Keller, P., and K. Simons. 1998. Cholesterol is required for surface transport of influenza virus hemagglutinin. J. Cell Biol. 140:1357-1367.

26. Kretzschmar, E., M. Bui, and J. K. Rose. 1996. Membrane association of influenza virus matrix protein does not require specific hydrophobic domains or the viral glycoproteins. Virology 220:37-45.

27. Kretzschmar, E., L. Buonocore, M. J. Schnell, and J. K. Rose. 1997. Highefficiency incorporation of functional influenza virus glycoproteins into recombinant vesicular stomatitis viruses. J. Virol. 71:5982-5989.

28. Kundu, A., R. T. Avalos, C. M. Sanderson, and D. P. Nayak. 1996. Transmembrane domain of influenza virus neuraminidase, a type II protein, possesses an apical sorting signal in polarized MDCK cells. J. Virol. 70:65086515 .

29. Lafont, F., S. Lecat, P. Verkade, and K. Simons. 1998. Annexin XIIIb associates with lipid microdomains to function in apical delivery. J. Cell Biol. 142:1413-1427.

30. Lamb, R. A., P. R. Etkind, and P. W. Choppin. 1978. Evidence for a ninth influenza viral polypeptide. Virology 91:60-78.

31. Lamb, R. A., S. L. Zebedee, and C. D. Richardson. 1985. Influenza virus $\mathrm{M}_{2}$ protein is an integral membrane protein expressed on the infected-cell surface. Cell 40:627-633.

32. Le Bivic, A., Y. Sambuy, K. Mostov, and E. Rodriguez-Boulan. 1990. Vectorial targeting of an endogenous apical membrane sialoglycoprotein and uvomorulin in MDCK cells. J. Cell Biol. 110:1533-1539.

33. Ledeen, R. W., R. K. Yu, and L. F. Eng. 1973. Gangliosides of human myelin: sialosylgalactosylceramide (G7) as a major component. J. Neurochem. 21: 829-839.

34. Lin, S., H. Y. Naim, A. C. Rodriguez, and M. G. Roth. 1998. Mutations in the middle of the transmembrane domain reverse the polarity of transport of the influenza virus hemagglutinin in MDCK epithelial cells. J. Cell Biol. 142:5157.

35. Lisanti, M. P., I. W. Caras, M. A. Davitz, and E. Rodriguez-Boulan. 1989. A glycophospholipid membrane anchor acts as an apical targeting signal in polarized epithelial cells. J. Cell Biol. 109:2145-2156.

36. Macala, L. J., R. K. Yu, and S. Ando. 1983. Analysis of brain lipids by high performance thin-layer chromatography and densitometry. J. Lipid Res. 24:1243-1250.

37. Martin, K., and A. Helenius. 1991. Nuclear transport of influenza virus ribonucleoproteins: the viral matrix protein (M1) promotes export and inhibits import. Cell 67:117-130.

38. Melkonian, K. A., A. G. Ostermeyer, J. Z. Chen, M. G. Roth, and D. A. Brown. 1999. Role of lipid modifications in targeting proteins to detergentresistant membrane rafts. Many raft proteins are acylated, while few are prenylated. J. Biol. Chem. 274:3910-3917.

39. Millan, J., and M. A. Alonso. 1998. MAL, a novel integral membrane protein of human T lymphocytes, associates with glycosylphosphatidylinositol-anchored proteins and Src-like tyrosine kinases. Eur. J. Immunol. 28:36753684 .

40. Mitnaul, L. J., M. R. Castrucci, K. G. Murti, and Y. Kawaoka. 1996. The cytoplasmic tail of influenza A virus neuraminidase (NA) affects NA incorporation into virions, virion morphology, and virulence in mice but is not essential for virus replication. J. Virol. 70:873-879.

41. Montixi, C., C. Langlet, A. M. Bernard, J. Thimonier, C. Dubois, M. A. Wurbel, J. P. Chauvin, M. Pierres, and H. T. He. 1998. Engagement of T cell receptor triggers its recruitment to low-density detergent-insoluble membrane domains. EMBO J. 17:5334-5348.

42. Moran, M., and M. C. Miceli. 1998. Engagement of GPI-linked CD48 contributes to TCR signals and cytoskeletal reorganization: a role for lipid rafts in $\mathrm{T}$ cell activation. Immunity 9:787-796.

43. Nobusawa, E., T. Aoyama, H. Kato, Y. Suzuki, Y. Tateno, and K. Nakajima. 1991. Comparison of complete amino acid sequences and receptor-binding properties among 13 serotypes of hemagglutinin of influenza A viruses. Virology 182:475-485.

44. O'Neill, R. E., J. Talon, and P. Palese. 1998. The influenza virus NEP (NS2 protein) mediates the nuclear export of viral ribonucleoproteins. EMBO J. 17:288-296.

45. Paterson, R. G., and R. A. Lamb. 1993. The molecular biology of influenza viruses and paramyxoviruses, p. 35-73. In A. Davidson and R. M. Elliott (ed.), Molecular virology: a practical approach. IRL Oxford University Press, Oxford, England.

46. Pekosz, A., and R. A. Lamb. 1999. Cell surface expression of biologically active influenza $\mathrm{C}$ virus HEF glycoprotein expressed from cDNA. J. Virol. 73:8808-8812.

47. Pekosz, A., and R. A. Lamb. 1997. The CM2 protein of influenza C virus is an oligomeric integral membrane glycoprotein structurally analogous to influenza A virus M2 and influenza B virus NB proteins. Virology 237:439-51.

47a.Pimplikar, S. W., E. Ikonen, and K. Simons. 1994. Basolateral protein transport in streptolysin O-permeabilized MDCK cells. J. Cell Biol. 125: 1025-1035.

48. Puertollano, R., F. Martin-Belmonte, J. Millan, M. del Carmen de Marco, J. P. Albar, L. Kremer, and M. A. Alonso. 1999. The MAL proteolipid is necessary for normal apical transport and accurate sorting of the influenza virus hemagglutinin in Madin-Darby canine kidney cells. J. Cell Biol. 145: $141-151$.

49. Rodriguez-Boulan, E., K. T. Paskiet, P. J. Salas, and E. Bard. 1984. Intracellular transport of influenza virus hemagglutinin to the apical surface of Madin-Darby canine kidney cell. J. Cell Biol. 98:308-319.

50. Romanoff, A. L. 1960. The avian embryo, p. 1039-1140. The Macmillan Company, New York, N.Y.

51. Scheiffele, P., J. Peranen, and K. Simons. 1995. N-glycans as apical sorting signals in epithelial cells. Nature 378:96-98.

52. Scheiffele, P., A. Rietveld, T. Wilk, and K. Simons. 1999. Influenza viruses select ordered lipid domains during budding from the plasma membrane. J. Biol. Chem. 274:2038-2044.

53. Scheiffele, P., M. G. Roth, and K. Simons. 1997. Interaction of influenza virus haemagglutinin with sphingolipid-cholesterol membrane domains via 
its transmembrane domain. EMBO J. 16:5501-5508.

54. Schroeder, R., E. London, and D. Brown. 1994. Interactions between saturated acyl chains confer detergent resistance on lipids and glycosylphosphatidylinositol (GPI)-anchored proteins: GPI-anchored proteins in liposomes and cells show similar behavior. Proc. Natl. Acad. Sci. USA 91:12130-12134.

55. Simons, K., and E. Ikonen. 1997. Functional rafts in cell membranes. Nature 387:569-572.

56. Singer, S. J., and G. L. Nicolson. 1972. The fluid mosaic model of the structure of cell membranes. Science 175:720-731.

57. Skibbens, J. E., M. G. Roth, and K. S. Matlin. 1989. Differential extractability of influenza virus hemagglutinin during intracellular transport in polarized epithelial cells and nonpolar fibroblasts. J. Cell Biol. 108:821-832.

58. Sternberg, P. W., and S. L. Schmid. 1999. Caveolin, cholesterol and Ras signalling. Nat. Cell Biol. 1:E35-E37.

59. Sugawara, K., H. Nishimura, F. Kitame, and K. Nakamura. 1986. Antigenic variation among human strains of influenza $\mathrm{C}$ virus detected with monoclonal antibodies to gp88 glycoprotein. Virus Res. 6:27-32.

60. Varma, R., and S. Mayor. 1998. GPI-anchored proteins are organized in submicron domains at the cell surface. Nature 394:798-801.

61. Veit, M., G. Herrler, M. F. G. Schmidt, R. Rott, and H.-D. Klenk. 1990. The hemagglutinating glycoproteins of influenza B and $\mathrm{C}$ viruses are acylated with different fatty acids. Virology 177:807-811.

62. Veit, M., H.-D. Klenk, A. Kendal, and R. Rott. 1991. The M2 protein of influenza A virus is acylated. Virology 184:227-234.

63. Whittaker, G., I. Kemler, and A. Helenius. 1995. Hyperphosphorylation of mutant influenza virus matrix protein, M1, causes its retention in the nucleus. J. Virol. 69:439-445.

64. Xavier, R., T. Brennan, Q. Li, C. McCormack, and B. Seed. 1998. Membrane compartmentation is required for efficient T cell activation. Immunity 8:723732 .

65. Yeaman, C., A. H. Le Gall, A. N. Baldwin, L. Monlauzeur, A. Le Bivic, and E. Rodriguez-Boulan. 1997. The $O$-glycosylated stalk domain is required for apical sorting of neurotrophin receptors in polarized MDCK cells. J. Cell Biol. 139:929-940.

66. Zebedee, S. L., and R. A. Lamb. 1988. Influenza A virus $M_{2}$ protein: Monoclonal antibody restriction of virus growth and detection of $\mathrm{M}_{2}$ in virions. J. Virol. 62:2762-2772.

67. Zhang, J., and R. A. Lamb. 1996. Characterization of the membrane association of the influenza virus matrix protein in living cells. Virology 225:255266.

68. Zhang, J., G. P. Leser, A. Pekosz, and R. A. Lamb. The cytoplasmic tails of the influenza virus spike glycoproteins are required for normal genome packaging. Virology, in press.

69. Zhang, W., R. P. Trible, and L. E. Samelson. 1998. LAT palmitoylation: its essential role in membrane microdomain targeting and tyrosine phosphorylation during $\mathrm{T}$ cell activation. Immunity 9:239-246.

70. Zheng, X., D. Lu, and J. E. Sadler. 1999. Apical sorting of bovine enteropeptidase does not involve detergent-resistant association with sphingolipidcholesterol rafts. J. Biol. Chem. 274:1596-1605. 